\title{
1 Post-fire development of faunal habitat depends on plant regeneration traits
}

2 Frederick W. Rainsford ${ }^{1,2^{*}}$, Luke T. Kelly ${ }^{3}$, Steve W.J. Leonard ${ }^{4}$, Andrew F. Bennett ${ }^{1,2}$

$3{ }^{1}$ Department of Ecology Environment and Evolution, La Trobe University, Bundoora,

4 Victoria 3086 Australia.

$5 \quad 2$ Research Centre for Future Landscapes, La Trobe University, Bundoora, Victoria 3086

6 Australia

$7 \quad{ }^{3}$ School of Ecosystem and Forest Sciences, University of Melbourne, Parkville, Victoria 83052 , Australia.

$9{ }^{4}$ Department of Primary Industries, Parks, Water and Environment, Hobart Tasmania.

$10 *$ Corresponding author: Department of Ecology Environment and Evolution, La Trobe

11 University, Bundoora, Victoria 3086 Australia. Tel. +61 419685567. Email:

12 f.rainsford@latrobe.edu.au. ORCID: https://orcid.org/0000-0002-2316-9197.

Acknowledgements

We gratefully acknowledge funding and support for this project from the Holsworth Wildlife Research Endowment; Department of Environment, Land, Water and Planning (Victoria); and La Trobe University Department of Environment, Ecology and Evolution. We thank the following people who contributed to data collection and collation in the mallee: Sarah Avitabile, Lauren Brown, Kate Callister, Mike Clarke, Angie Haslem, Greg Holland, Sally Kenny, Dale Nimmo, Lisa Spence-Bailey, Rick Taylor and Simon Watson. All authors contributed critically to the drafts and gave final approval for publication. The authors have no conflicts of interest to declare. Field work was conducted under Scientific Permit no. 100008333 (DELWP, Vic) We thank two anonymous reviewers for constructive feedback that improved the final version.

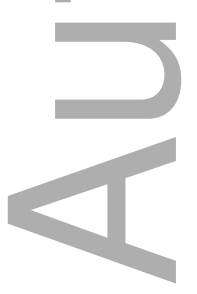

This is the author manuscript accepted for publication and has undergone full peer review but has not been through the copyediting, typesetting, pagination and proofreading process, which may lead to differences between this version and the Version of Record. Please cite this article as doi: 10.1111/AEC.12896

This article is protected by copyright. All rights reserved 
Article type : Research Article

Post-fire development of faunal habitat depends on plant regeneration traits

\section{Abstract}

The concept that vegetation structure (and faunal habitat) develops predictably with time since fire has been central to understanding the relationship between fire and fauna. However, because plants regenerate after fire in different ways (e.g. resprouting from above-ground stems vs. underground lignotubers), use of simple categories based on time-since-fire might not adequately represent post-fire habitat development in all ecosystems. We tested the hypothesis that the post-fire development of faunal habitat structure differs between ecosystems, depending on fire regeneration traits of the dominant canopy trees. We measured 12 habitat components at sites in foothill forests $(n=38)$, heathy woodlands $(n=38)$ and mallee woodlands $(n=98)$ in Victoria, Australia and used generalised additive models to predict changes in each variable with time since fire. A greater percentage of faunal habitat variables responded significantly to time since fire in mallee woodlands, where fires typically are stand-replacing, than in foothill forests and heathy woodlands, where canopy tree stems generally persist through fire. In the ecosystem with the highest proportion of epicormic resprouters (foothill forests), only ground cover and understorey vegetation responded significantly to time since fire, compared with all but one variable in the ecosystem dominated by basal resprouters (mallee woodlands). These differences between ecosystems in the post-fire development of key habitat components suggest there may also be fundamental differences in the role of fire in shaping the distribution of fauna. If so, this challenges the way in which many fire-prone ecosystems are currently categorised and managed, especially the level of dependence on time since fire and other temporal surrogates 
habitat structural development, additional complexity (e.g. fire severity, topography, prior land-use history) could better capture processes that determine faunal occurrence in fireprone ecosystems.

\section{Key words}

Ecosystem, epicormic resprouting, eucalypt, faunal habitat, post-fire succession, plant regeneration traits, time since fire.

\section{Introduction}

Fire-prone ecosystems have evolved under particular temporal and spatial patterns of fire occurrence (Bond and Keeley 2005, Archibald et al. 2018, Pausas and Parr 2018). Consequently, plants have regeneration strategies that help them survive and reproduce after fire, such as resprouting from dormant buds and fire-cued germination (Pausas and Keeley 2014). However, in many regions fire regimes are changing. First, with climate change, many regions are becoming hotter and drier, increasing the likelihood of more frequent and severe wildfires in many forests and woodlands (Bradstock 2010, Stephens et al. 2013). Second, contemporary fire-management activities such as fire suppression and prescribed burning may be incongruous with natural or historic regimes (Giljohann et al. 2015, Connell et al. 2017). Third, humans have altered ignition patterns and the spread of fire through land-use changes (Bowman et al. 2011). In the face of such changes, understanding the relationships between fire, plant regeneration and faunal habitat development is essential to conserve faunal diversity while also achieving other management goals.

Fire can affect the distribution of fauna directly by removing individuals, and indirectly by changing vegetation composition and structure and, therefore, the available habitat (Fox et al. 2003, Pausas and Parr 2018). Understanding how habitat changes through time in fire-prone ecosystems can help ecologists and land managers to better predict the impact of fire on fauna and identify species that could potentially be at risk due to changing fire regimes (Haslem et al. 2011). Indeed, the time between fires is widely used as a surrogate for animal and plant distributions, an idea captured by related terms in the fire ecology literature including 'age-classes' and 'successional states' (Cohn et al. 2015, Giljohann et al. 2015).

A common management paradigm is based on the idea that post-fire vegetation development follows a successional pathway that facilitates faunal occupancy associated with different successional states. Support for this approach has come from studies of taxa in a range of 
ecosystems: for example, small mammals in shrubby heathlands in Australia (Fox 1982) and in savannas of the Brazilian Cerrado (Briani et al. 2004); reptiles in semi-arid woodlands in Australia (Nimmo et al. 2012); and birds in boreal forests in Canada (Haney et al. 2008) and in shrublands in the European Pyrenees (Pons and Clavero 2010). In each of these systems, the association of faunal species with post-fire successional states is linked to changes in vegetation structure that enhance faunal habitat. An emphasis on post-fire succession underpins current fire management in our study region, the state of Victoria, Australia. Landscape-scale fire management is guided by two main measures: Tolerable Fire Interval (TFI) and Vegetation Growth Stage Structure (GSS) (York and Friend 2016). Tolerable fire intervals are determined for stands of vegetation based on the minimum and maximum intervals between fires that will prevent plant species loss (Cheal 2010). Vegetation Growth Stages are time-since-fire categories assumed to represent distinct assemblages of flora, fauna and habitat attributes (Cheal 2010). Fire management aims to maintain desirable combinations of Growth Stages in land scapes to conserve biodiversity. The applicability of these measures requires that biodiversity values develop predictably with time since fire.

Ecosystems may vary in the way in which vegetation structural changes correspond to time since last fire. In some ecosystems, such as those listed above, fires typically are 'standreplacing': above-ground vegetation is removed, and regeneration occurs from the ground-up (et al. 2005, Clarke et al. 2010). In others, such as Pinus canariensis woodlands on Canary Island (Pausas and Keeley 2017) and stringybark eucalypt forests in Australia (Burrows 2013), canopy tree stems generally persist through fire and regeneration occurs rapidly, facilitated by epicormic buds. Thus, the role of time since fire in the long-term development of vegetation structure (and faunal habitat) may differ fundamentally between ecosystems: for example muted influence of time since fire on vertebrates in temperate eucalypt forests (Kelly et al. 2017) compared to a strong influence on fauna in stand-replacing ecosystems (e.g. Pons and Clavero 2010, Watson et al. 2012, ). If this is true, there may be a need to rethink the way in which some fire-prone ecosystems are currently categorised and managed. For example, if faunal habitat does not change predictably with time since fire in all ecosystems, then management strategies could be more effective by concentrating on the actual habitat features that influence fauna.

We sampled vegetation structural attributes across a chronosequence of time since fire in three eucalypt-dominated ecosystems in Victoria, south-eastern Australia: foothill forests, heathy woodlands and mallee woodlands to compare the post-fire dynamics of faunal habitat 
structure. These three ecosystems are dominated by Eucalyptus species with contrasting fire regeneration traits. The thick-barked canopy trees in foothill forests generally survive fire and regenerate rapidly from protected epicormic buds along the trunk and branches (Fig. 1a $-\mathrm{c})$. Canopy trees in heathy woodlands may survive fire and regenerate from epicormic buds, or basally from lignotubers (Fig. 1d-e). Fires in mallee woodlands typically are standreplacing: the above-ground vegetation is consumed by fire and the canopy trees resprout basally from lignotubers, such that the system regenerates from the ground-up (Fig. $1 \mathrm{f}-\mathrm{g}$ ).

We aimed to capture elements of the ground cover, understorey vegetation and canopy structure (Table 1) that represent important habitat attributes for faunal species in forests and wood lands (Table 2). For example, leaf litter and understorey shrubs provide foraging substrate, shelter and nesting sites for birds, invertebrates, reptiles and terrestrial mammals (Fox et al. 2003, McElhinny et al. 2006, Kelly et al. 2011, Nimmo et al. 2012); and large trees provide resources such as den sites, nest hollows and foraging substrates for arboreal mammals and hollow-nesting birds (McElhinny et al. 2006, Bennett 2016). Understanding the post-fire dynamics of these habitat attributes will provide insight into how time since fire influences the distribution of faunal species within fire-prone ecosystems.

We hypothesised that the post-fire development of faunal habitat structure differs between ecosystems, depending on the extent to which fire is stand-replacing for the dominant canopy trees, or whether canopy tree stems persist and recover rapidly. Specifically, we address the following predictions: (1) the number and breadth of habitat structural components that respond to time since fire will be greater in ecosystems in which fires typically are standreplacing than in ecosystems where canopy tree stems persist through fire; (2) in ecosystems in which canopy tree stems persist through fire, components of the ground layer structure will be driven by time since fire, but not components of the canopy structure; and (3) in ecosystems in which fires are stand-replacing, the development of all main habitat structural components will be driven by time since fire.

\section{Methods}

Study location and ecosystems

We studied three eucalypt-dominated ecosystems in Victoria, Australia: foothill forests, heathy woodlands and mallee woodlands (Fig. 2). A key difference between these distinct ecosystems is the proportion of epicormic resprouting trees vs. basal resprouting trees. Related differences, such as local climate, topography and fire regimes are described below. 
128 The generic term 'foothill forests' refers to temperate eucalypt forests that occur on the lower- to mid-slopes of the Great Dividing Range, covering $~ 75000 \mathrm{~km}^{2}$ in Victoria. The climate is temperate with a mean annual rainfall of $\sim 850 \mathrm{~mm}$. The highest rainfall occurs in winter (August) and the hottest month is February (mean daily maximum $\sim 29^{\circ} \mathrm{C}$ ) (Lake Eildon, station no.083023; http://www.bom.gov.au/). Foothill forests occur on mountainous terrain, often with steep slopes and densely-vegetated gullies. Elevation in the study area ranges between $\sim 450$ and $950 \mathrm{~m}$ above sea-level.

Heathy woodlands occur sparingly throughout coastal areas of south-eastern Australia on nutrient-poor, deep sandy soils of quartzite gravel. The climate in the heathy woodlands study area is also temperate with a mean annual rainfall ranging from $540-895 \mathrm{~mm}$. The highest rainfall occurs in winter (August) and the hottest month is February (mean daily maximum $28^{\circ} \mathrm{C}$ ) (Mount Gellibrand, station no. 0900351, Cape Otway lighthouse, station no. 090015; http://www.bom.gov.au/). The topography in the heathy woodlands study area is gently undulating with elevation ranging between $\sim 40$ and $250 \mathrm{~m}$ above sea-level.

Mallee woodlands cover an area of $\sim 100000 \mathrm{~km}^{2}$ in the semi-arid zone of south-eastern Australia. Summers are hot and dry, and winters are mild. Mean annual rainfall is $\sim 290 \mathrm{~mm}$. The highest rainfall occurs in spring and the hottest month is January (mean daily maximum $\sim 32^{\circ} \mathrm{C}$ ) (Mildura Airport, station no. 076031; http://www.bom.gov.au/). Mallee woodlands occur on low-lying ( $\leq 100 \mathrm{~m}$ above sea-level) terrain with little topographic variation. An extensive dune-swale system characterises the region with sandy dunes receding to clayey swales.

Vegetation

Foothill forests are the tallest of the three ecosystems, with canopy trees reaching heights of $30-60 \mathrm{~m}$, often accompanied by a secondary tree layer of Acacia spp. The term 'foothill forests' encapsulates several similar but distinct vegetation communities, ranging from wetter forest-types in gullies to drier forest-types on ridge tops and steep north-facing slopes. To avoid inherent differences in vegetation composition and structure between gullies and ridges, sites in this study were limited to a single Ecological Vegetation Class (EVC): 'herbrich foothills forest' (Victorian Government Department of Sustainability and Environment 2004a). The dominant canopy species at these sites were messmate stringybark (Eucalyptus obliqua), broad-leaved peppermint (E. dives), narrow- leaved peppermint (E. radiata), and 
mountain grey-gum (E. cypellocarpa). Small trees and shrubs constitute the understorey, including blackwood (Acacia melanoxylon), prickly currant-bush (Coprosma quadrifida), common cassinia (Cassinia aculeata), and ferns such as austral bracken (Pteridium esculentum). The ground layer consists of a rich cover of herbs.

In heathy woodlands, a low canopy $(\leq 10 \mathrm{~m})$ of eucalypts occurs over a diverse array of ericoid-leaved shrubs that form a dense understorey over time, following disturbance. The dominant canopy species are brown stringybark (E. baxteri) and western peppermint (E. fasciata). The main understorey shrubs include austral grass tree (Xanthorrhoea australis), heath tea-tree (Leptospermum myrsinoides), prickly tea-tree (L. continentale) and silver banksia (Banksia marginata) (Victorian Government Department of Sustainability and Environment 2004b). Fire regeneration traits of understorey species vary: tea trees resprout from basal lignotubers, austral grasstree resprouts apically, and silver banksia regenerates from seed.

Mallee woodlands are characterised by a low $(\leq 6 \mathrm{~m})$ canopy of multi-stemmed Eucalyptus species. Three broad vegetation types have been described in this system; Triodia Mallee, Chenopod Mallee and Heathy Mallee, based on their floristic and structural differences (Haslem et al. 2010). We limited this study to Triodia Mallee because responses of both flora and fauna to fire can differ between vegetation types (Haslem et al. 2011). The low canopy is generally dominated by dumosa mallee (E. dumosa) and grey mallee (E. socialis). The understorey is dominated by porcupine grass (Triodia scariosa) and Acacia spp.

Fire regimes

In all three ecosystems, wild fires typically occur in summer (Dec - February), whereas prescribed burns are undertaken in autumn and spring months. Large wildfires (> $10000 \mathrm{ha}$ ) have occurred within the wider foothill forests region in 1939, 1962, 1983, 2003, 2005, 2006, 2009 and 2014 (Victorian Government Department of Environment, Land, Water and Planning 2015), and in the mallee woodlands region they occur approximately decadally (Avitabile et al.2013). Prescribed burning is undertaken in all three ecosystems to achieve management goals relating to fuel reduction and ecosystem resilience. Minimum tolerable fire intervals are used to guide the timing of prescribed burns: these are 15 years for foothill forests, 12 years for heathy woodlands and 25 years for mallee woodlands (Cheal 2010). In foothill forests, but not heathy woodlands, prescribed burns typically do not scorch the 
212

213

canopy (Gill 2012). In mallee woodlands, both wildfires and prescribed burns typically are stand-replacing.

Study design

We employed a space-for-time approach in each ecosystem to compare the post-fire development of key faunal habitat components. Sites were selected to span a chronosequence from one (foothill forest and heathy woodlands) or two years (mallee woodlands) to 80 years post-fire, and to cover a range of post-fire successional states based on the Vegetation Growth Stages described by Cheal (2010) (see Appendix S1).

We sampled foothill forests from 38 sites positioned on slopes at least $100 \mathrm{~m}$ from a gully and $50 \mathrm{~m}$ from a ridge top within an $\sim 320 \mathrm{~km}^{2}$ area of the Highlands Southern Fall (-37.516 S, 146.042 E), heathy woodlands from 38 sites within an $100 \mathrm{~km}^{2}$ area of the Great Otway National Park and Forest Park (-38.608 S, 143.346 E), and used data collected from 98 sites within a $4200 \mathrm{~km}^{2}$ area of the Murray-Sunset and Hattah-Kulkyne National Parks (-34.757 S, 141.628 E) in north-west Victoria (Fig. 2).

There were a greater number of sites in the mallee woodlands as these were surveyed as part of a project that investigated the responses of multiple taxa to fire mosaics across the whole Murray-Mallee region, covering parts of Victoria, New South Wales and South Australia (Haslemet al. 2012, Nimmo et al. 2012, Watson et al. 2012). To reduce the influence of rainfall and temperature gradients on vegetation structure (Kenny et al. 2018), this study was restricted to mallee sites within Victoria. There were disproportionately more sites in the 1135 years-since-fire category, so we took a random sample of 21 sites from this growth stage to ensure even coverage of the chronosequence (Appendix S1).

Fire history

The fire history of foothill forests and heathy woodlands sites was determined by using spatial data maps of fire history supplied by the Victorian Department of Environment, Land, Water and Planning, and analysed using the software ArcMap (ESRI 2011). The mapped time since fire was ground-truthed at each site by looking for signs of charring on eucalypt bark and other structural features of the vegetation.

The fire history of sites in mallee woodlands was ascertained in two ways. For sites burnt post 1972, Landsat imagery and existing fire mapping were used to determine the exact year of the last fire (Avitabile et al. 2013). For sites burnt prior to 1972, time since fire was 
deduced by using regression models of the relationship between stem diameter and tree age (time since fire) (Clarke et al. 2010).

Fires of different severity can affect habitat structural components differently in some vegetation types (Bassett et al. 2017). Prescribed burns, undertaken for fire management in cooler periods, are usually of a lower intensity than wildfires and tend not to reach the canopy in foothill forests. To control for fire severity in foothill forests, fire-type of the last fire was limited to prescribed burns at all sites, except for the oldest time since fire. Prescribed burns were not used routinely in fire management until the 1970s, so sites burnt prior to this were last burnt during a 1939 wildfire. Because of recent large wildfires in the study area, limiting fire-type to wildfire while covering an adequate range of age-classes was not possible without introducing effects of climate and environmental gradients. Previous work in foothill forests found that fire-type had a relatively minor influence on the distributions of species at temporal scales similar to that used here (Kelly et al. 2017).

Heathy woodlands were sampled at sites burnt either during prescribed burns or wildfires as there were insufficient sites available within a single fire-type. Based on observations of resprouting eucalypts, fire severity does not vary greatly between prescribed burns and wildfires in heathy woodlands because both fire-types typically reach the canopy. In mallee woodlands, both prescribed burns and wildfires also generally reach the canopy, consume above- ground vegetation and are stand-replacing (Haslem et al. 2011); as such, both firetypes were included for these two systems.

\section{Data collection}

We sampled faunal habitat structural components in each ecosystem covering three broad categories: (i) ground cover, (ii) understorey vegetation and (iii) canopy structure (Table 1).

The type of ground cover and the depth of leaf litter $(\mathrm{cm})$ were recorded at $1 \mathrm{~m}$ intervals along a $50 \mathrm{~m}$ transect, and these data were used to calculate percentage cover of different ground cover types and mean litter depth, respectively. At each point ( $1 \mathrm{~m}$ interval) the number of intercepts of living vegetation in different height categories was recorded using a 2 $m$ ranging pole and these data were used to estimate the precent cover of understorey vegetation.

To assess the canopy structure in each ecosystem, we recorded the number and diameter at breast height $(\mathrm{DBH})$ of living eucalypt trees at each site. In foothill forests, we used the point- 
277

centred quarter method (PCQM) (Cottam and Curtis 1956). At each site, two parallel transects were established $40 \mathrm{~m}$ apart that ran perpendicular to the slope. At 10 points at $20 \mathrm{~m}$ intervals along each transect (total of 20 points per site) we measured the DBH and distance to the nearest tree in each quarter of 360 degrees (total of 80 stems per site). A minimum of 20 points ( 80 stems) is required to estimate canopy tree density in forests (Ruch et al. 2008). In heathy woodlands a $4 \mathrm{~m} \times 250 \mathrm{~m}$ quadrat, and in mallee woodlands a $4 \mathrm{~m} \times 50 \mathrm{~m}$ quadrat were used to record canopy trees. To compare the post-fire development of habitat structural components between ecosystems, we then calculated 12 variables considered to be important for fauna within each ecosystem (Table 1). Differences between ecosystems in the size categories for certain variables represent inherent differences in vegetation structure.

Data analysis

We used generalised additive models (GAMs) to determine the relationship between faunal habitat structure variables (Table 1) and time since fire (years). From visualisation of the observed data and consultation with the literature, GAMs were deemed appropriate as they model both linear and non-linear relationships and are useful when responses are unknown a priori. Generalised additive modelling is a regression modelling technique that uses a smoothing term to fit response curves to predictor variables (Wood 2017). We used a mixedmodel approach (GAMM) for mallee woodlands as these data were collected from points clustered in landscapes (Haslem et al. 2011). Mixed models were fitted with landscape unit (1 -12) as a random effect to account for spatial autocorrelation among sampled sites. Residual plots were examined to assess adherence to assumptions of normality of variance prior to analysis. Degrees of freedom $(\mathrm{K})$ for the smoothing term was initially set at four for all variables. However, model exploration indicated better models were fitted when $\mathrm{K}$ was set to three for the following variables: bare ground cover, mean diameter of large trees, and maximum tree diameter.

All analyses were conducted using the $\mathrm{R}$ statistical environment ( $\mathrm{R}$ Development Core Team 2013) and the mgcv package (Wood 2018) and source scripts adapted from Elith et al. (2008) to calculate model deviance.

\section{Results}

There were differences between ecosystems in the percentage of faunal habitat structure variables that responded to time since fire. In foothill forests, 33\% (4/12) of variables had a 
significant response (i.e. p-values of regression models $<0.05$ ) to time since fire, compared with 58\% (7/12) in heathy woodlands and 92\% (11/12) in mallee woodlands (Fig. 3).

Foothill forests

In foothill forests, two of the four ground cover variables, litter cover $(\mathrm{P}<0.001)$ and litter depth ( $\mathrm{P}<0.001)$, increased significantly with time since fire (Fig. 3). Litter cover increased rapidly, reaching a peak at $<20$ years since fire, whereas litter depth increased linearly across the chronosequence. Both lower- $(\mathrm{P}<0.001)$ and upper-midstorey $(\mathrm{P}<0.01)$ vegetation cover increased with time since fire. However, none of the canopy structure variables showed a significant response to time since fire.

Heathy woodlands

In heathy woodlands, three of the four ground cover variables, bare ground cover $(\mathrm{P}<0.001)$ litter cover $(\mathrm{P}<0.001)$ and litter depth $(\mathrm{P}<0.001)$, responded to time since fire (Fig. 3). Bare ground cover decreased rapidly to almost zero in late-successional states. Litter cover increased rapidly until $\sim 20$ years since fire, after which it plateaued. Litter depth increased until $\sim 25$ years since fire and then decreased before plateauing. Both lower- $(\mathrm{P}<0.01)$ and upper-midstorey $(\mathrm{P}<0.001)$ vegetation cover responded to time since fire. Lower-mid storey vegetation increased until $\sim 25$ years since fire, then decreased to plateau at $\sim 60$ years since fire. Upper-midstorey vegetation cover plateaued at $\sim 50$ years since fire. Two of the five canopy structure variables, basal area $(\mathrm{P}<0.05)$ and maximum tree diameter $(\mathrm{P}<0.01)$ increased moderately with time since fire.

Mallee woodlands

All but one of the faunal habitat structure variables that were modelled in mallee woodlands responded significantly to time since fire (Fig. 3). Bare ground cover $(\mathrm{P}<0.001)$ decreased with time since fire until 40 years post-fire. Litter cover $(\mathrm{P}<0.001)$ and litter depth $(\mathrm{P}<$ $0.01)$ both increased linearly with time since fire. Plant cover increased with time since fire, but this was not significant $(\mathrm{P}=0.283)$. Lower- midstorey vegetation cover decreased with time since fire $(\mathrm{P}<0.01)$. Upper-mid storey vegetation cover showed a bell-shaped response, peaking at $\sim 30$ years since fire $(\mathrm{P}<0.01)$. The size, density and distribution of large trees all increased, whereas tree density $(\mathrm{P}<0.01)$ decreased linearly with increasing time since fire.

Model outputs can be found in Appendix S2. 


\section{Discussion}

314 This study shows that the post-fire development of habitat structural variables differs between ecosystems, and that these patterns are consistent with the fire regeneration traits of the dominant tree species. In mallee woodlands, where fires typically are stand-replacing, more structural components were driven by time since fire than in foothill forests and heathy woodlands, where stands of canopy trees generally persist though fire. The shape of the fireresponse curve for most structural components also differed between ecosystems. For faunal species that respond to these habitat structural components, there may be fundamental differences between ecosystems in the role of fire in shaping distributional patterns. These findings have implications for the way in which ecosystems are categorised and managed for biodiversity conservation, which we discuss in the sections below.

Temporal development of faunal habitat structure

Most notably, the three ecosystems differed in the post-fire development of canopy structure. In mallee woodlands, all variables measuring canopy structure responded to time since fire. Overall, the observed pattern was for large trees to increase in mean diameter, occur at a higher density and constitute a greater proportion of all canopy trees, in later successional states. In mallee woodlands, the above ground component of canopy trees typically is killed by fire and resprouts basally from lignotubers, and so stands of canopy trees take decades following fire to grow to maturity (Clarke et al. 2010). Resprouting from basal buds is the most common form of post-fire resprouting, globally (Pausas and Keeley 2017). This trait is especially prevalent in drier biomes of lower productivity where crown fires are experienced (Clarke et al. 2013), like semi-arid woodlands.

In recently burnt mallee woodlands, the density of live stems was high because of vigorous resprouting but decreased over time as canopy trees grow. Some resources that large trees provide for faunal species, such as tree hollows, take many decades to develop and are not present until later successional states ( 60 years since fire) (Haslem et al. 2012). As a result of the slow development of these and other resources (e.g. hummock grass), many faunal species in mallee wood lands are associated with mid-later successional vegetation (Kelly et al. 2012, Connell et al. 2017).

By contrast, in foothill forests, where stands of canopy trees survive fire and resprout epicormically, none of the canopy variables we modelled responded to time since fire. These structural variables are proxies for important resources for animals provided by the forest 
canopy. For example, the availability of tree hollows that provide essential nesting and shelter sites for arboreal mammals and hollow-nesting birds is directly related to the distribution of large trees (Lindenmayer et al. 1993, Remm and Lõhmus 2011). In foothill forests, large canopy trees were still present immediately after fire and throughout the chronosequence, thus serving as biological legacies (Pulsford et al. 2016) that do not depend on time since fire. Further, the percentage of trees in the canopy stratum that were 'very large' was generally modest $(\sim 25 \%)$ across the range of successional states. This suggests that canopy tree regeneration in foothill forests happens continually and does not follow a clear post-fire successional pathway.

Globally, epicormic resprouting is rare in ecosystems that experience high-intensity crownfire regimes, such as Mediterranean-type and warm-temperate forests and woodlands (Pausas and Keeley 2017). Taxa that resprout epicormically, additional to Eucalyptus species, include Pinus canariensis on Canary Island, Protea nitida in South Africa, Quercus agrifolia, Q. kelloggii in California and Q. suber in the Mediterranean Basin (Pausas and Keeley 2017). This adaptation enables rapid canopy regeneration and makes these species and their associated habitat features resilient to most fire regimes. Epicormic resprouting is also widespread in tree species in grassy-savanna ecosystems (e.g. in northern Australia) that experience frequent grass-fuelled fires. In such savanna ecosystems, fire frequency, fire season and fire severity are more influential fire parameters for biota than simply the time since last fire (Murphy et al. 2010, Andersen et al. 2012). These ecosystems represent examples of situations where simple classifications based on time since fire may not be sufficient to capture fire-driven dynamics for faunal species.

In south-eastern Australia, recent large wildfires in foothill forests have reduced the temporal range of post-fire successional states associated with wildfire. Consequently, to cover the breadth of age-classes without introducing effects of vegetation type, climate and environmental gradients, it was necessary to sample prescribed burns for age-classes $<80$ years since fire. A limitation is that we may have underestimated the potential effects of severe fires on habitat structure. However, Haslem et al. (2016) showed that the main effect of fire severity in foothill forests is on canopy cover, and this effect diminishes rapidly (after $\sim 10$ years since fire). The interacting effects of fire severity and time since fire on habitat structure would be a fruitful area for further research. 
In general, the cover of understorey vegetation responded positively to time since fire in all three ecosystems, except for lower-midstorey vegetation in mallee woodlands which responded negatively. However, the shapes of the responses differed: in foothills forests upper-midstorey cover increased rapidly and peaked earlier than in both heathy woodlands and mallee woodlands. Similar patterns to those shown here have been observed previously in temperate eucalypt forests (Swan et al. 2015, Haslem et al. 2016) and mallee woodlands (Haslem et al. 2011). Understorey vegetation provides nesting, foraging and shelter sites for many bird and mammal species typical of these and similar ecosystems (Ford et al. 1986, Fox et al. 2003, Simonetti et al. 2013, Swan et al. 2015, Verdon et al. 2019). Consequently, the temporal responses of such faunal species to fire are likely to be positively influenced by these post-fire trajectories in habitat suitability (e.g. Fox 1982, Watson et al. 2012). However, early post-fire succession can also create short-term opportunities for species that favour more-open habitats and which decline in occurrence as understorey vegetation recovers (e.g. Watson et al. 2012).

Biomass allocation in plants (i.e. habitat structure for animals) depends on environmental factors as well as disturbance regimes (Clarke et al. 2013). Factors, such as climate, soils and productivity influence development of habitat structural components: plant growth rate is higher in mesic than semi-arid biomes. Environmental influences will be most evident when comparing structural components that are removed by fire and regenerate from the ground-up (e.g. rate of increase in understorey vegetation). However, plant regeneration traits are fundamental in explaining the differences we observed between ecosystems, as they provide the mechanism that determines whether or not key structures are present within certain successional states.

Fire regeneration traits and ecosystem succession

Support for the idea that, following fire, vegetation development follows a successional pathway that facilitates faunal occupancy has mainly come from studies of stand-replacing ecosystems (Briani et al. 2004, Haney et al. 2008, Pons and Clavero 2012, Watson et al. 2012). In such stand-replacing ecosystems, categories based on time since fire have proved useful for predicting landscape-scale impacts of fire on faunal species (Connell et al. 2017, Regos et al. 2018). In contrast, in epicormic-resprouting systems, in which canopy tree stems generally persist though fire, the successional pathway is not reset to 'time-zero' by burning. Rather, the occurrence and distribution of some key structures, such as large trees tend to be a 
legacy from past disturbances rather than a product of the time since the last fire. If key components of habitat structure, such as large trees and their associated resources, do not show strong temporal patterns of post-fire development, the fauna that rely on those components are less likely to be associated with distinct successional stages. In epicormic resprouting ecosystems such as the foothill forests, the resources provided by canopy trees in forests and woodlands (e.g. foliage, hollows, bark, large limbs, flowers: Table 2), are important for a wide range of faunal species (McElhinny et al. 2006). Consequently, in such ecosystems, categorising landscapes into successional states is likely to be less useful for predicting the landscape-scale impacts of fire.

\section{Implications for fire management}

The primary finding of this study, that post-fire development of faunal habitat components differs between ecosystems, has implications for the way in which fire-prone ecosystems are understood and subsequently managed. The habitat components studied here are surrogates for important resources for fauna, so differences in their pattern of post-fire development are likely to influence the fire-responses of species that rely on them. Clearly, an important next step is to directly test the relative influence of time-since-fire on faunal species in these disparate ecosystems.

If differences between ecosystems in the fire-response of habitat components reflect real differences in the role of time since fire in shaping faunal distributions, then it will be necessary to rethink how some landscapes are understood and categorised for fire management. For example, fire managers often aim to maintain mosaics of post-fire vegetation age-classes (surrogates of time since fire) across the landscape (Bradstock et al. 2005). This approach is likely to be more effective in maintaining biodiversity values in ecosystems in which vegetation age-classes are structurally and functionally distinct, and support distinct faunal assemblages (Kelly et al. 2012, Watson et al. 2012). Where there is less difference between age-classes, and factors such as pre-fire structure and environmental gradients are influential (e.g. in foothill forests), a more nuanced approach that recognisees both time since fire and the biological legacy of historical disturbance regimes, is required.

We recommend that when using a patch mosaic approach in landscape-scale fire management, the 'patches' incorporate the most ecologically meaningful fire regime and environmental parameters. For example, in grassy savanna ecosystems of northern Australia (Davies et al. 2018) and conifer forests of western U.S.A. (Tingley et al 2016), management 
strategies that aim to maintain patch mosaics based on fire frequency and fire severity, rather than simply time since fire, are understood to benefit biodiversity across land scapes. In foothill forests, an approach that similarly incorporates additional complexity (beyond time since fire) could improve conservation management outcomes for fauna. A key question to address is 'how do other aspects of the fire regime (e.g. fire severity) and environmental conditions (e.g. topography) interact with time since fire to influence faunal species at the landscape scale'?

\section{Conclusions and future directions}

Incorporating the needs of fauna into fire management remains a challenge in fire-prone regions worldwide. Our finding that the regeneration traits of the dominant canopy species in wooded ecosystems influences the development of key habitat components, suggests there are fundamental differences in the mechanisms underpinning fire-habitat-fauna dynamics between disparate ecosystems. In systems where fire is not stand-replacing, the persistence of pre-fire structural attributes (e.g. tree size, tree density) as post-fire legacies can mediate the influence of temporal post-fire succession. The next step is to directly examine how the coupling of time since fire and habitat structural development influences the distribution of faunal species in disparate ecosystems, to test whether observed differences in habitat dynamics equate to real influence on the occurrence and status of faunal species.

\section{References}

Archibald, S., C. E. R. Lehmann, C. M. Belcher, W. J. Bond, R. A. Bradstock, A. L. Daniau, K. G. Dexter, E. J. Forrestel, M. Greve, T. He, S. I. Higgins, W. A. Hoffmann, B. B. Lamont, D. J. McGlinn, G. R. Moncrieff, C. P. Osborne, J. G. Pausas, O. Price, B. S. Ripley, B. M. Rogers, D. W. Schwilk, M. F. Simon, M. R. Turetsky, G. R. Van Der Werf, and A. E. Zanne. 2018. Biological and geophysical feedbacks with fire in the Earth system. Environmental Research Letters 13.

Andersen, A., J.C.Z. Woinarski, and C.L. Parr. 2012. Savanna burning for biodivserity: fire management for faunal conservation in Australian tropical savannas. Austral Ecology 37:658-667.

Avitabile, S. C., K. E. Callister, L. T. Kelly, A. Haslem, L. Fraser, D. G. Nimmo, S. J. Watson, S. A. Kenny, R. S. Taylor, L. M. Spence-Bailey, A. F. Bennett, and M. F. 
Clarke. 2013. Systematic fire mapping is critical for fire ecology, planning and management: A case study in the semi-arid Murray Mallee, south-eastern Australia. Landscape and Urban Planning 117:81-91.

Bassett, M., S. W. J. Leonard, E. K. Chia, M. F. Clarke, and A. F. Bennett. 2017. Interacting effects of fire severity, time since fire and topography on vegetation structure after wildfire. Forest Ecology and Management 396:26-34.

Bennett, A.F. 2016. Eucalypts, wild life and nature conservation: from individual trees to landscape patterns. Proceedings of the Royal Society of Victoria 128:71-86.

Bond, W. J., and J. E. Keeley. 2005. Fire as a global 'herbivore': the ecology and evolution of flammable ecosystems. Trends in Ecology \& Evolution 20:387-394.

Bowman, D. M. J. S., J. K. Balch, P. Artaxo, W. J. Bond, M. A. Cochrane, C. M. D’Antonio, R. S. DeFries, F. H. Johnston, J. E. Keeley, M. A. Krawchuk, C. A. Kull, M. Mack, M. A. Moritz, S. Pyne, C. I. Roos, A. C. Scott, N.S. Sodhi, T. W. Swetnam. 2011. The human dimension of fire regimes on Earth. Journal of Biogeography 12:2223-2236.

Bradstock, R. A., M. Bedward, A. M. Gill, and J. S. Cohn. 2005. Which mosaic? A landscape ecological approach for evaluating interactions between fire regimes, habitat and animals. Wildlife Research 32:409-423.

Bradstock, R. A. 2010. A biogeographic model of fire regimes in Australia: current and future implications. Global Ecology and Biogeography 19:145-158.

Briani, D. C., A. R. T. Palma, E. M. Vieira, and R. P. B. Henriques. 2004. Post-fire succession of small mammals in the Cerrado of central Brazil. Biodiversity \& Conservation 13:1023-1037.

Burrows, G. E. 2013. Buds, bushfires and resprouting in the eucalypts. Australian Journal of Botany $61: 331-349$.

Cheal, D. 2010. Growth stages and tolerable fire intervals for Victoria's native vegetation data sets. Arthur Rylah Institute for Environmental Research, Victorain Government Department of Sustainability and Environment, Melbourne. 
Clarke, M. F., S. C. Avitabile, L. Brown, K. E. Callister, A. Haslem, G. J. Holland, L. T. Kelly, S. A. Kenny, D. G. Nimmo, L. M. Spence-Bailey, R. S. Taylor, S. J. Watson, and A. F. Bennett. 2010. Ageing mallee eucalypt vegetation after fire: insights for successional trajectories in semi-arid mallee ecosystems. Australian Journal of Botany 58:363-372.

Clarke, P. J., M. J. Lawes, J. J. Midgley, B. B. Lamont, F. Ojeda, G. E. Burrows, N. J. Enright, and K. J. E. Knox. 2013. Resprouting as a key functional trait: how buds, protection and resources drive persistence after fire. New Phytologist 197:19-35.

Cohn, J. S., J. DiStefano, F. Christie, G. Cheers, and A. York. 2015. How do heterogeneity in vegetation types and post-fire age-classes contribute to plant diversity at the landscape scale? Forest Ecology and Management 346:22-30.

Connell, J., S. J. Watson, R. S. Taylor, S. C. Avitabile, R. H. Clarke, A. F. Bennett, and M. F. Clarke. 2017. Testing the effects of a century of fires: Requirements for post-fire succession predict the distribution of threatened bird species. Diversity and Distributions 23:1078-1089.

Cottam, G., and J.T. Curtis. 1956. The use of distance measure in phytosociological sampling. Ecology 37:451-460.

Davies, H.F., M.A. McCarthy, W. Rioli, J. Puruntatameri, W. Roberts, C. Kerinaiua, V. Kerunaiua, K.B. Womatakimi, A.N. Andersen and B.P. Murphy. 2018. An experimental test of whether pyrodiversity promotes mammal diversity in a northern Australian savanna. Journal of Applied Ecology 55 :2124-2134.

Elith, J., J. R. Leathwick, and T. Hastie. 2008. A working guide to boosted regression trees. Journal of Animal Ecology $77: 802-813$.

Ford, H. A., S. Noske, and L. Bridges. 1986. Foraging of birds in eucalypt woodland in north-eastern New South Wales. Emu 86:168-179.

Fox, B. J. 1982. Fire and mammalian secondary succession in an Australian coastal heath. Ecology 63:1332-1341. 
Fox, B. J., J. E. Taylor, and P. T. Thompson. 2003. Experimental manipulation of habitat structure: a retrogression of the small mammal succession. Journal of Animal Ecology 72:927-940.

Giljohann, K. M., M. A. McCarthy, L. T. Kelly, and T. J. Regan. 2015. Choice of biodiversity index drives optimal fire management decisions. 25:264-277.

Gill, A. M. 2012. Bushfires and biodiversity in southern Australian forests. Pages 235-252 in R. Bradstock, A. M. Gill, and R. J. Williams, editors. Flammable Australia: fire regimes, biodiversity and ecosystems in a changing world. CSIRO Publishing, Collingwood, Victoria, Australia.

Haney, A., S. Apfelbaum, and J. M. Burris. 2008. Thirty years of post-fire succession in a southern boreal forest bird community. The American Midland Naturalist 159:421433.

Haslem, A., K. E. Callister, S. C. Avitabile, P. A. Griffioen, L. T. Kelly, D. G. Nimmo, L. M. Spence-Bailey, R. S. Taylor, S. J. Watson, L. Brown, A. F. Bennett, and M. F. Clarke. 2010. A framework for mapping vegetation over broad spatial extents: A technique to aid land management across jurisdictional boundaries. Landscape and Urban Planning 97:296-305.

Haslem, A., L. T. Kelly, D. G. Nimmo, S. J. Watson, S. A. Kenny, R. S. Taylor, S. C. Avitabile, K. E. Callister, L. M. Spence-Bailey, M. F. Clarke, and A. F. Bennett. 2011. Habitat or fuel? Implications of long-term, post-fire dynamics for the development of key resources for fauna and fire. Journal of Applied Ecology 48:247256.

Haslem, A., S. C. Avitabile, R. S. Taylor, L. T. Kelly, S. J. Watson, D. G. Nimmo, S. A. Kenny, K. E. Callister, L. M. Spence-Bailey, A. F. Bennett, and M. F. Clarke. 2012. Time-since-fire and inter-fire interval influence hollow availability for fauna in a fireprone system. Biological Conservation 152:212-221.

Haslem, A., S. W. J. Leonard, M. J. Bruce, F. Christie, G. J. Holland, L. T. Kelly, J. MacHunter, A. F. Bennett, M. F. Clarke, and A. York. 2016. Do multiple fires interact 
to affect vegetation structure in temperate eucalypt forests? Ecological Applications 26:2414-2423.

Keeley, J. E., C. J. Fotheringham, and M. Baer-Keeley. 2005. Determinants of postfire recovery and succession in mediterranean-climate shrublands of California. Ecological Applications 15:1515-1534.

Kelly, L. T., D. G. Nimmo, L. M. Spence-Bailey, A. Haslem, S. J. Watson, M. F. Clarke, and A. F. Bennett. 2011. Influence of fire history on small mammal distributions: insights froma 100-year post-fire chronosequence. Diversity and Distributions 17:462-473.

Kelly, L. T., D. G. Nimmo, L. M. Spence-Bailey, R. S. Taylor, S. J. Watson, M. F. Clarke, and A. F. Bennett. 2012. Managing fire mosaics for small mammal conservation: a landscape perspective. Journal of Applied Ecology 49:412-421.

Kelly, L. T., A. Haslem, G. J. Holland, S. W. Leonard, J. MacHunter, M. Bassett, A. F. Bennett, M. J. Bruce, E. K. Chia, F. J. Christie, M.F. Clarke, J. Di Stefano, R. Loyn, M.A. McCarthy, A. Pung, N. Robinson, H. Sitters, M. Swan and A. York. 2017. Fire regimes and environmental gradients shape vertebrate and plant distributions in temperate eucalypt forests. Ecosphere 8(4):e01781.

Kenny, S. A., A. F. Bennett, M. F. Clarke, and J. W. Morgan. 2018. Time-since-fire and climate interact to affect the structural recovery of an Australian semi-arid plant community. Austral Ecology 43:456-469.

Lindenmayer, D. B., R. B. Cunningham, C. F. Donnelly, M. T. Tanton, and H. A. Nix. 1993. The abundance and development of cavities in Eucalyptus trees: a case study in the montane forests of Victoria, southeastern Australia. Forest Ecology and Management 60:77-104.

McElhinny, C., P. Gibbons, C. Brack and J. Brauhus. 2006. Fauna-habitat relationships: a basis for identifying key stand structural attributes in temperate Australian eucalypt forests and woodlands. Pacific Conservation Biology 12:89-110. 
Murphy, B. P., J. Russell-Smith, and L.D. Lynda. 2010. Frequent fires reduce tree growth in northern Australin savannas: implications for tree demography and carbon sequestration. Global Change Biology 16:331-343.

Nimmo, D. G., L. T. Kelly, L. M. Spence-Bailey, S. J. Watson, A. Haslem, J. G. White, M. F. Clarke, and A. F. Bennett. 2012. Predicting the century-long post-fire responses of reptiles. Global Ecology and Biogeography $21: 1062-1073$.

Pausas, J. G., and J. E. Keeley. 2014. Evolutionary ecology of resprouting and seeding in fire-prone ecosystems. New Phytologist 204:55-65.

Pausas, J. G., and J. E. Keeley. 2017. Epicormic resprouting in fire-prone ecosystems. Trends Plant Science 22:1008-1015.

Pausas, J. G., and C. L. Parr. 2018. Towards an understanding of the evolutionary role of fire in animals. Evolutionary Ecology 32:113-125.

Pons, P., and M. Clavero. 2010. Bird responses to fire severity and time since fire in managed mountain rangelands. Animal Conservation 13:294-305.

Pulsford, S. A., D. B. Lindenmayer, and D. A. Driscoll. 2016. A succession of theories: purging redundancy from disturbance theory. Biological Reviews 91:148-167.

Remm, J., and A. Lõhmus. 2011. Tree cavities in forests - the broad distribution pattern of a keystone structure for biodiversity. Forest Ecology and Management 262:579-585.

Regos, A., Hermoso, V., D'Amen, M., Guisan, A. \& Brotons, L. (2018). Trade-offs and synergies between bird conservation and wildfire suppression in the face of global change. Journal of Applied Ecology 55:2181-2192.

Ruch, D.G., B.G. Torke, K.S. Badger and C.R. Reidy. 2008. Point-centred quarter analysis of four forest types at Hayes Arboretum in Wayne County, Indiana. Proceedings of the Indiana Academy of Science 117:136-141.

Simonetti, J. A., A. A. Grez, and C. F. Estades. 2013. Providing habitat for native mammals through understory enhancement in forestry plantations. Conservation Biology 27:1117-1121.

This article is protected by copyright. All rights reserved 
Stephens, S. L., J. K. Agee, P. Z. Fulé, M. P. North, W. H. Romme, T. W. Swetnam, and M. G. Turner. 2013. Managing forests and fire in changing climates. Science 342:41-42.

Swan, M., F. Christie, H. Sitters, A. York, and J. Di Stefano. 2015. Predicting faunal fire responses in heterogeneous landscapes: the role of habitat structure. Ecological Applications $25: 2293-2305$.

Verdon, S., S. Watson, and M.F. Clarke. 2019. Modelling variability in the fire-response of an endangered bird to improve fire management. Ecological Applications 0:e01980.

Victorian Government Department of Sustainability and Environment. 2004a.

EVC/Biore gion benchmark for vegetation quality assessment: Highlands - Southern Fall bioregion, EVC 23: Herb-rich Foothill Forest. Victorian Government Department of Sustainability and Environment.

Victorian Government Department of Sustainability and Environment. 2004b. EVC/Bioregion benchmark for vegetation quality assessment: Otway Plain bioregion, EVC 48: Heathy Woodland. Victorian Government Department of Sustainability and Environment.

Victorian Government Department of Environment, Land, Water and Planning 2015. Strategic bushfire management plan: East Central. Victorian Government Department of Environment, Land, Water and Planning, Victoria, Australia.

Watson, S. J., R. S. Taylor, D. G. Nimmo, L. T. Kelly, A. Haslem, M. F. Clarke, and A. F. Bennett. 2012. Effects of time since fire on birds: How informative are generalized fire response curves for conservation management? Ecological Applications 22:685696.

Wood, S.N. 2017. Genarlized additive models: an introduction with R ( $2^{\text {nd }}$ edition). Chapman nad Hall/CRC, Boca Raton.

York, A. and G. Friend. 2016. Towards and ecologically sustainable fire management strategy. The Victorian Naturalist 133:165-171. 
631 Table 1. Habitat structure variables calculated for three eucalypt-dominated ecosystems (foothill forests, heathy woodlands, mallee woodlands) in south-

632 eastern Australia. The range of values for each variable in each ecosystem is given, together with a description of the variable.

\begin{tabular}{|c|c|c|c|c|c|}
\hline Habitat category & Variable & Foothill forests & Heathy woodlands & Mallee woodlands & Description \\
\hline \multirow{4}{*}{ Ground cover } & Bare ground cover & $0-70$ & $0-76$ & $4-94$ & Percent $(\%)$ cover of bare ground \\
\hline & Litter cover & $28-100$ & $20-98$ & $0-90$ & Percent $(\%)$ cover of leaf litter \\
\hline & Litter depth & $0.4-9.4$ & $0.13-4.1$ & $0-2.7$ & Mean depth of leaf litter $(\mathrm{cm})$ \\
\hline & Plant cover & $0-32$ & $0-32$ & $0-28$ & Percent (\%) cover of plants (includes shrubs, herbs and ferns) \\
\hline \multirow[t]{2}{*}{ Understorey } & Lower-midstorey & $21-89$ & $42-96$ & $0-54$ & Percent $(\%)$ cover of vegetation $0-1 \mathrm{~m}(\mathrm{FF}, \mathrm{HW}), 0-0.5 \mathrm{~m}(\mathrm{MW})$ \\
\hline & Upper-midstorey & $0-33$ & $6-67$ & $0-39$ & Percent $(\%)$ cover of ve getation $1-4 \mathrm{~m}(\mathrm{FF}, \mathrm{HW}), 0.5-2 \mathrm{~m}(\mathrm{MW})$ \\
\hline \multirow[t]{6}{*}{ Canopy } & Basal area & $23-76$ & $0.37-2.22$ & $0-6.9$ & Basal area cover of canopy trees $\left(\mathrm{m}^{2} / \mathrm{ha}\right)$ \\
\hline & $\begin{array}{l}\text { Density of large } \\
\text { trees }\end{array}$ & $147-324$ & $200-1280$ & $0-1800$ & $\begin{array}{l}\text { Density (live stems/ha) of canopy trees with diameter greater than the median } \\
\text { for that ecosystem ( }>25 \mathrm{~cm} \mathrm{FF} ;>8 \mathrm{~cm} \mathrm{HW} ;>4 \mathrm{~cm} \mathrm{MW} \text { ). }\end{array}$ \\
\hline & $\begin{array}{l}\text { Maximum tree } \\
\text { diameter }\end{array}$ & $50-200$ & $16-60$ & $0-30$ & Diameter $(\mathrm{cm})$ of the largest tree within the sample area \\
\hline & $\begin{array}{l}\text { Mean diameter of } \\
\text { large trees }\end{array}$ & $34-59$ & $11.4-22.5$ & $0-15.5$ & $\begin{array}{l}\text { Mean diameter }(\mathrm{cm}) \text { of trees with diameter greater than median for the } \\
\text { ecosystem }(>25 \mathrm{~cm} \mathrm{FF} ;>8 \mathrm{~cm} \mathrm{HW} ;>4 \mathrm{~cm} \mathrm{MW})\end{array}$ \\
\hline & $\begin{array}{l}\text { Percentage of very } \\
\text { large trees }\end{array}$ & $11-45$ & $3-76$ & $0-100$ & $\begin{array}{l}\text { Percent }(\%) \text { of trees in the canopy stratum with diameter in the upper quartile } \\
\text { for the ecosystem ( }>39 \mathrm{~cm} \mathrm{FF} ;>12 \mathrm{~cm} \mathrm{HW} ;>7 \mathrm{~cm} \mathrm{MW})\end{array}$ \\
\hline & Tree density & $270-750$ & $500-2900$ & $150-2850$ & Density of canopy trees (live stems/ha) \\
\hline
\end{tabular}


Table 2. Key habitat attributes used by seven faunal groups, their associated resources and functions, and the habitat surrogate category used in our assessment. Adapted from a review by McElhinny et al. 2006 of fauna-habitat associations in Australian forests and woodlands.

\begin{tabular}{|c|c|c|c|}
\hline Taxonomic group & $\begin{array}{l}\text { Habitat attribute (McElhinny } \\
\text { et al. 2006) }\end{array}$ & $\begin{array}{l}\text { Associated resources/function } \\
\text { (McElhinny et al. 2006) }\end{array}$ & $\begin{array}{l}\text { Habitat surrogate category } \\
\text { (present study) }\end{array}$ \\
\hline Amphibians & $\begin{array}{l}\text { Vegetation cover } \\
\text { Ground debris }\end{array}$ & $\begin{array}{l}\text { Shelter, moist microclimate } \\
\text { Shelter, refuge, foaging }\end{array}$ & $\begin{array}{l}\text { Ground cover, unders torey } \\
\text { Ground cover }\end{array}$ \\
\hline \multirow[t]{4}{*}{ Arboreal mammals } & Foliage & Edible material & Canopy \\
\hline & Flowers & Nectar, pollen & Understorey, canopy \\
\hline & Bark & Exudates, invertebrates & Canopy \\
\hline & Tree hollows & Den/nest sites, water & Canopy \\
\hline \multirow[t]{6}{*}{ Birds } & Foliage & Exudates, invertebrates & Understorey, canopy \\
\hline & Flowers & Nectar, invertebrates & Understorey, canopy \\
\hline & Bark & Exudates, invertebrates & Canopy \\
\hline & Ground layer & Invertebrates, small vertebrates & Ground cover \\
\hline & Air spaces & Invertebrates & Understorey, canopy \\
\hline & Tree hollows & Nest sites, shelter & Canopy \\
\hline \multirow{3}{*}{ Bats (insectivorous) } & Foliage & Invertebrates & Understorey, canopy \\
\hline & Canopy space & Invertebrates & Understorey, canopy \\
\hline & Hollows, decorticating bark & Roost/nest sites & Canopy \\
\hline \multirow[t]{2}{*}{ Ground mammals } & Shrubs & Shelter & Understorey \\
\hline & Litter & Nesting, invertebrates, fungi & Ground cover \\
\hline \multirow[t]{5}{*}{ Invertebrates } & Foliage & Edible material, sap, shelter & Understorey, canopy \\
\hline & Flowers & Nectar, pollen & Understorey, canopy \\
\hline & Bark & Shelter, exudates, prey & Understorey, canopy \\
\hline & Shrubs & Foliage, flowers, shelter & Understorey \\
\hline & Litter, woody debris & Food, prey, shelter & Ground cover \\
\hline \multirow[t]{3}{*}{ Reptiles } & Basking sites & Temperature regulation & Ground cover \\
\hline & Litter & Invertebrates, cover & Ground cover \\
\hline & Shrubs & Cover, invertebrates & Understorey \\
\hline
\end{tabular}

637

\section{$638 \quad$ Figure captions}

639 Figure 1. Vegetation of the study ecosystems. 1. Foothill forests: (a) long unburnt vegetation 640 and $(b-c)$ epicormic resprouting in recently burnt eucalypts. 2. Heathy woodlands: (d) long 641 unburnt vegetation and (e) epicormic resprouting in recently burnt eucalypts. 3. Mallee 642 woodlands: (f) long unburnt vegetation and ( $\mathrm{g}$ ) recently burnt eucalypts resprouting from 
643 lignotubers. The blue and red arrow represents a gradient of stand-replacement (bottom) to 644 stand-survival (top). Photo credits: FR ( $\mathrm{a}-\mathrm{e})$, Mallee Fire and Biota Project ( $\mathrm{f}-\mathrm{g})$.

645 Figure 2. Locations of study areas in foothill forests, heathy woodlands and mallee 646 woodlands in Victoria, Australia, and the distribution of Ecological Vegetation Divisions 647 (EVDs) that correspond to the three ecosystems studied: foothill forests (green; EVDs = 648 foothills forest, forby forests), heathy woodlands (orange; EVD = heathland sands) and 649 mallee woodlands (red; EVDs = chenopod mallee, hummock-gras s mallee, lowan mallee) 650 (Victorian Department of Environment, Land, Water and Planning).

651 Figure 3. Predicted patterns of post-fire temporal dynamics of faunal habitat components in 652 foothills forests (solid green lines), heathy woodlands (orange dot-dashed lines) and mallee 653 woodlands (red dashed lines). Lines are fitted smoothed terms from generalised additive 654 models and shaded areas are 95\% confidence intervals. Asterisks represent significance level 655 of the smoothed term: $* \mathrm{P}<0.05$, $* * \mathrm{P}<0.01$, ***<0.001, ns $=$ not significant. Lines with no 656 shaded ribbon represent non-significant relationships. 'Large' and 'very large' trees refer to 657 trees with trunk diameter above the median, and within the upper quartile for that ecosystem, 658 respectively.

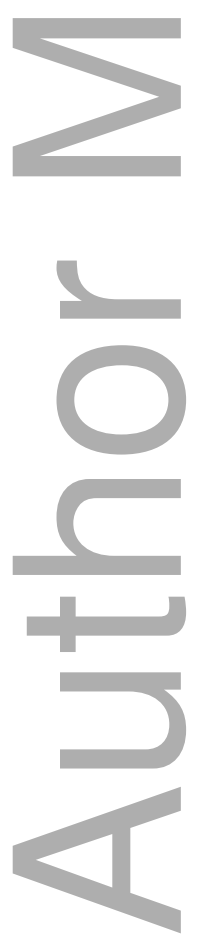




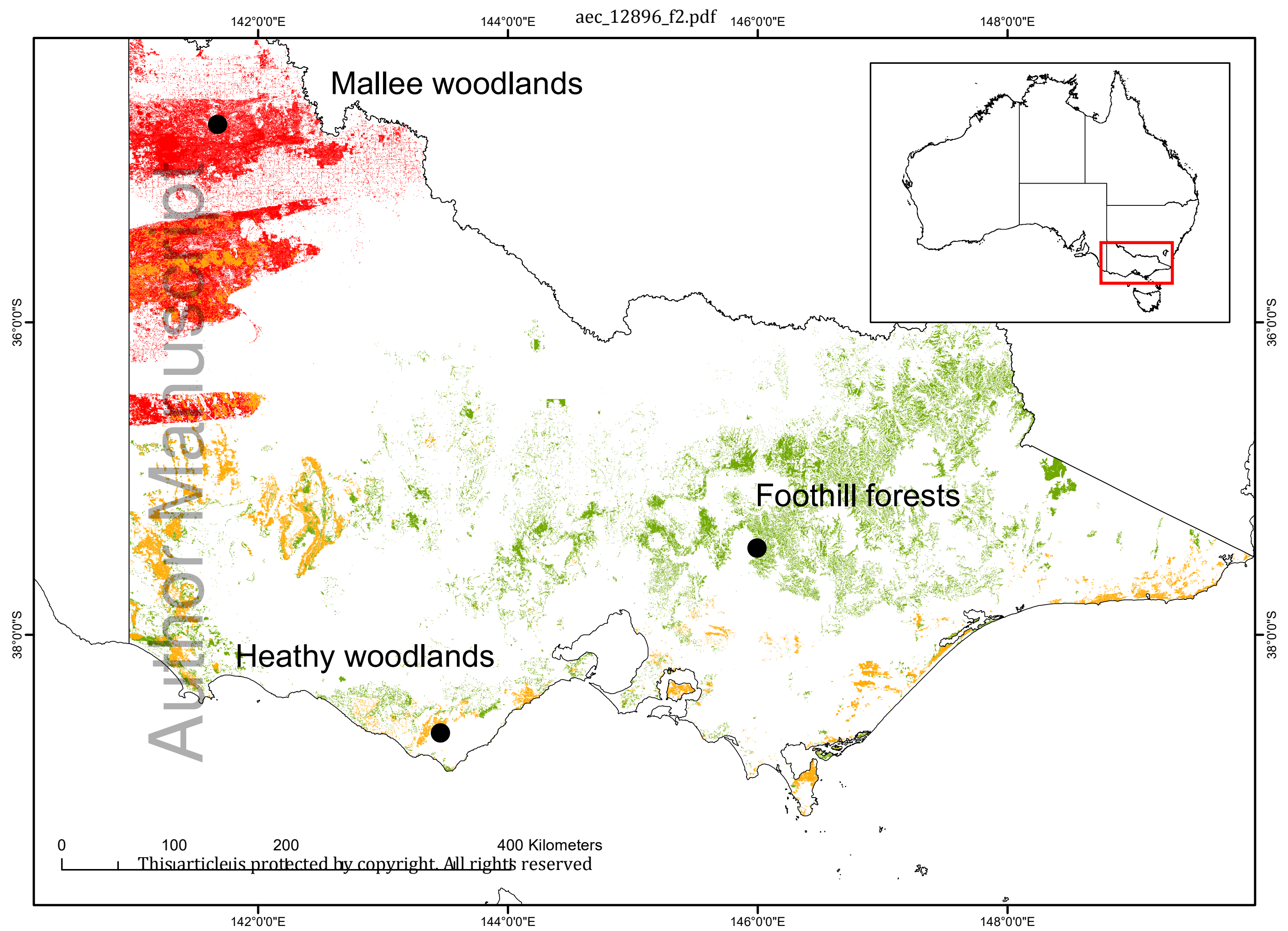



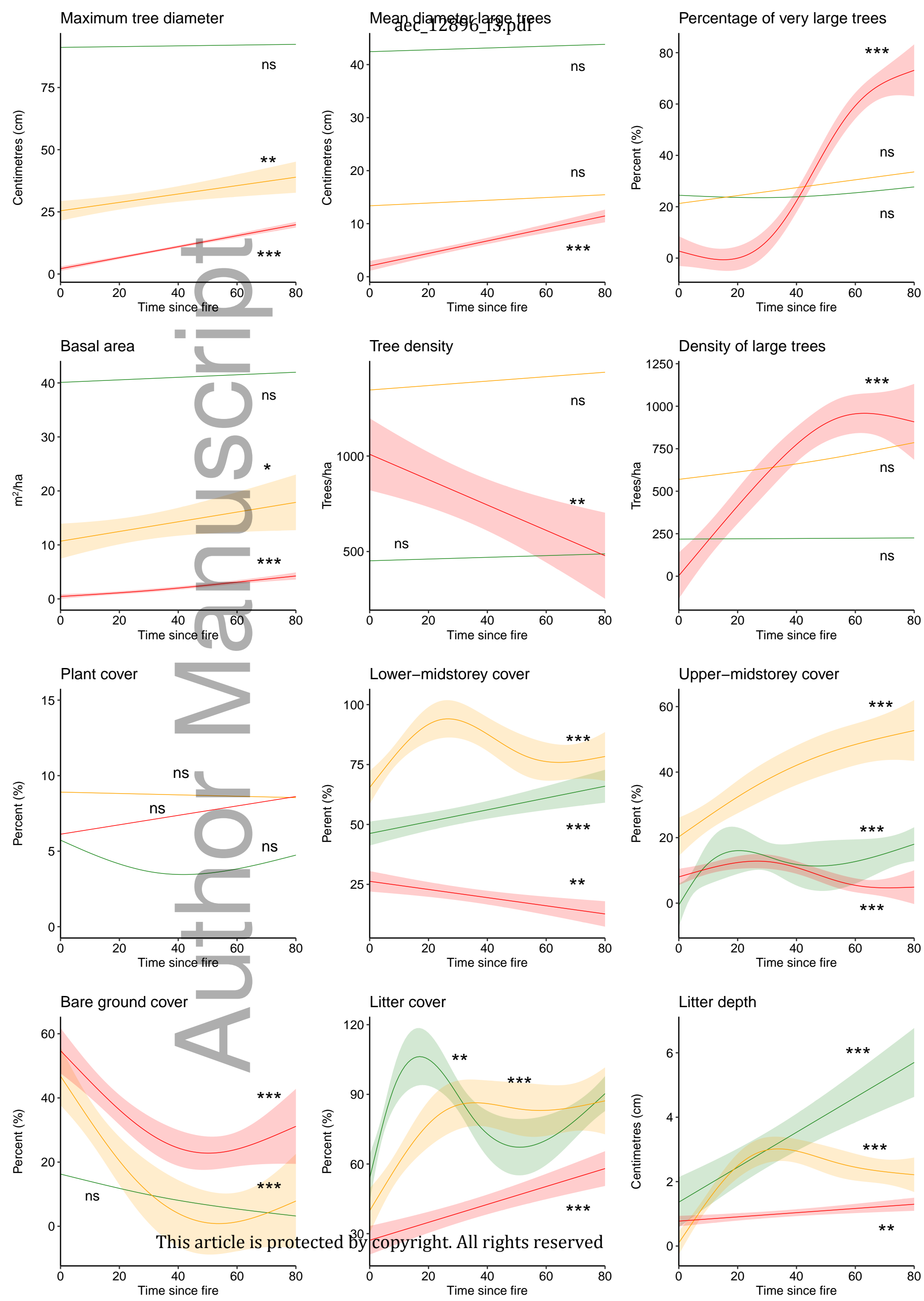


\section{University Library}

\section{- M M N E R VA A gateway to Melbourne's research publications}

Minerva Access is the Institutional Repository of The University of Melbourne

Author/s:

Rainsford, FW;Kelly, LT;Leonard, SWJ;Bennett, AF

Title:

Post-fire development of faunal habitat depends on plant regeneration traits

Date:

2020-09

Citation:

Rainsford, F. W., Kelly, L. T., Leonard, S. W. J. \& Bennett, A. F. (2020). Post-fire development of faunal habitat depends on plant regeneration traits. AUSTRAL ECOLOGY, 45 (6), pp.800-812. https://doi.org/10.1111/aec.12896.

Persistent Link:

http://hdl.handle.net/11343/275954 